eCommons@AKU

January 2010

\title{
HIV/AIDS-related human security risks for young women in rural Uganda
}

Shelley Jones

Aga Khan University, shelley.jones@aku.edu

Follow this and additional works at: http://ecommons.aku.edu/eastafrica_ied

Part of the Gender and Sexuality Commons, and the Women's Studies Commons

\section{Recommended Citation}

Jones, S. (2010). HIV/AIDS-related human security risks for young women in rural Uganda. Canadian Journal of African Studies/La Revue canadienne des études africaines, 44(3), 579-604.

Available at: http://ecommons.aku.edu/eastafrica_ied/26 


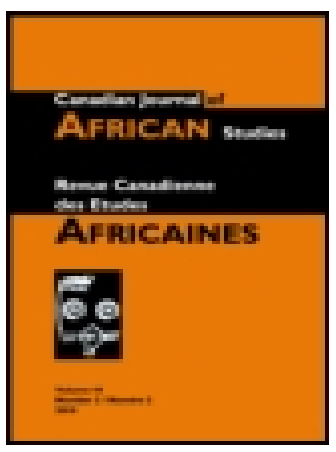

\section{Canadian Journal of African Studies / Revue canadienne} des études africaines

\section{HIV/AIDS-related Human Security Risks for Young Women in Rural Uganda}

\section{Shelley Jones}

To cite this article: Shelley Jones (2010) HIVIAIDS-related Human Security Risks for Young Women in Rural Uganda, Canadian Journal of African Studies / Revue canadienne des études africaines, 44:3, 579-604

To link to this article: http://dx.doi.org/10.1080/00083968.2010.9707546

曲 Published online: 09 Nov 2011.

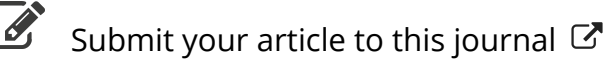

Цll Article views: 78

Q View related articles ¿ 


\title{
HIV/AIDS-related Human Security Risks for Young Women in Rural Uganda
}

\author{
Shelley Jones
}

\section{Résumé}

Les inégalités structurelles, la violence et l'oppression rendent les jeunes Ougandaises rurales très vulnérables au VIH/sida. Leur pouvoir de décision et de contrôle sur leur corps et leur sexualité et l'accès aux ressources en santé sexuelle sont extrêmement limités, voire entièrement absents. Pourtant, les programmes sur le VIH/sida en vigueur, notamment le President's Emergency Program for AIDS Relief (PEPFAR), mettent l'accent sur la modification des comportements individuels pour lutter contre le VIH/sida au détriment de considérations plus larges sur la société. Cette étude explore le vécu d'un groupe de jeunes femmes ougandaises et fait valoir que la bataille politique et idéologique pour l'appropriation - tant nationale que mondiale - du discours de prévention du VIH/sida non seulement ne tient pas compte des expériences de ces jeunes femmes mais mine aussi leur sécurité humaine en aggravant davantage leur susceptibilité à cette maladie. Pour que soient efficaces les interventions sur le VIH/sida, je maintiens que les politiques nationales et distales mondiales et les priorités de programmation doivent s'inspirer des facteurs socioéconomiques et culturels complexes et nuancés du contexte local.

\section{Abstract}

Structural inequities, violence and oppression render young women in rural Uganda highly vulnerable to HIV/AIDS. Their decision-making powers, control over their bodies and sexuality, and access to sexual health resources are critically limited or wholly absent. Yet, prevailing HIV/AIDS programming, notably the President's Emergency Program for AIDS Relief (PEPFAR), emphasizes individual behaviour change to combat HIV/AIDS at the expense of wider societal considerations. This study explores the life experiences of a group of young Ugandan women and argues that the political and ideological battle of ownership national as well as global - over the HIV/AIDS prevention discourse not only disregards these young women's experiences, but also undermines 
their human security by further exacerbating their vulnerability to the disease. I maintain that if HIV/AIDS interventions are to be effective, the complex and nuanced socio-economic and cultural factors of local context must inform national and distal global policies and programming priorities.

\section{Introduction}

Prossy was my sister. She married a man with HIV positive and she got AIDS from that man ... [she] reached on the stage of not knowing everything about the world and without meat on her body she stayed with only bones on her body until she dead. She lost her baby with that disease. In fact, that baby suffered a lot [more] than her mother because ... treatment help the baby to grow and she gets some education. When she reached at the age of 16, AIDS became problem to that girl ... at 20 years she died ... I fear AIDS... ("A Story About AIDS" - from Caroline's notebook, October 2004).

Young women in rural Uganda have witnessed the ravages of HIV/AIDS on their families and communities. They are acutely aware of their own susceptibility to the disease and live with chronic fear of becoming one of its victims. This study explores the vulnerability to HIV/AIDS of a group of young women in rural Uganda in relation to recent trends in HIV/AIDS policy and programming at both the national and global levels. I argue that in order to mitigate human insecurity related to HIV/AIDS for one of the most vulnerable demographics, that of young women in SubSaharan Africa, successful interventions must take into consideration both the complex and nuanced socio-economic and cultural factors of local context, as well as the impact of distal global policies and programming priorities. It is of critical importance that structural inequities, injustices, violence and oppression at all levels - local, national and global - that undermine the personal security of young women in the face of HIV/AIDS be acknowledged. In this article I address the systemic conditions and problems (local, national and global) that undermine human security for young women in the face of HIV/AIDS in Uganda.

\section{Research Context and Participants}

The group of young women, aged fifteen to twenty-one years, who 
participated in this study, represents the population at highest risk of contracting HIV/AIDS in Uganda, and perhaps in the world. Fifty per cent of the HIV-infected population in Africa is youth, and the female-to-male ratio of HIV amongst adolescents is four to one (Neema and Bataringaya 2000). Research indicates that girls in the fifteen- to nineteen-year age range are up to six times more likely to contract HIV than boys in their age cohort (Dworkin and Erhardt 2007; Malinga 2001; Mirembe and Davies 2001; Okuonzi and Epstein 2005; Schoepf 2003). Females are more prone to infection for physiological reasons because the HIV viral load is denser in semen than in vaginal fluid and the vaginal wall is highly susceptible to ulcerations and chaffing (Kuate-Defo 2004). In addition to physiological factors, however, numerous other gender-related factors (such as gender-based violence, cultural practices that discriminate against women, and socio-economic inequities and societal norms) contribute enormously to the risk of young women contracting HIV/AIDS (Garbus and Marseille 2003; Jones and Norton, forthcoming; Roberts 2006; Schoepf 2003). Furthermore, young women's precipitous vulnerability to HIV/AIDS reflects human security deficits at both the micro and macro levels.

Data for this particular study come from a twelve-month (August 2004-August 2005) ethnographic study of a group of secondary school girls in rural Uganda, as well a subsequent research project, Digital Literacy, Gender and Access to Health Information, August-September, 2006. ${ }^{1}$ The young women who participated in this study were originally part of a class cohort at Kyato Secondary School (KSS), located in Kyato Village, Masaka District, in southwestern Uganda. Kyato Village borders a trading centre that is approximately seven miles from the nearest urban centre, Ganda, with a population of approximately seventy thousand. Poverty in this rural area of the country is endemic and acute. Most of the young women's families survived by subsistence-level farming, with small incomes sometimes earned through men's employment (for example, as labourers or in other occupations, such as tailoring or driving taxis), the sale of crafts such as mats and baskets made by women and girls, or the sale of extra food grown in the family gardens. The official per capita income is less than one dollar US per day (Uganda Bureau of Statistics 2002), although it is likely that many entire families live on less. Malnutrition, disease, 
and poor living conditions are widespread, and it has been one of the areas in the world hardest hit by the HIV/AIDS pandemic.

At the start of the research project, fifteen girls who participated in my research were in their final term of Senior Three, or S3 (the equivalent of grade ten). By the end of the field research in 2004 they had just begun Senior Four (S4), their final year of lower secondary. Upon their completion of S4, twelve girls continued with secondary education: seven pursued academic (A-Level) programs, and five pursued vocational training (tailoring, secretarial and hairdressing programs). These twelve girls participated in a subsequent six-week research project, Digital Literacy, Gender and Access to Health Information. The findings from the subsequent research indicated that girls did not receive sufficient health (particularly sexual health) education, and therefore sought to understand the kinds of knowledge, questions and experiences they did possess, as well as ways in which their access to the internet, and their ability to use it effectively, might empower them with in terms of health-related choices and decision-making.

Data for this article was collected using interviews, observations, questionnaires, journals, and document analysis, as well as data from the Digital literacy, gender and access to health information study, including three questionnaires (hereafter referred to as Q1, Q2 and Q3), coursework and notebooks of the participants, and written observations and oral communication (e-mail and verbal). As will be discussed in the following sections, the lives of each of the girls in this study has been severely affected by HIV/AIDS (such as death of parents, siblings, relatives and friends), and they live with the perpetual threat of infection. I examine these lived experiences in the context of feminist security theory.

\section{Theoretical Perspectives}

For this study, I invoke a theoretical framework of analysis based on Feminist Security Theory (FST), as defined by Blanchard (2003): ... the foundation of FST combines a rejection of realism, an interrogation of the abstractions of strategic discourse, an awareness of the connection between women's everyday experience and security, a critique of the state, and the recognition of the effects of structural violence with a strong normative and transformative vision, evidenced by its focus on inequality and 
emancipation (1298).

FST broadens the understanding of security from one focused on national boundaries to one in which "The end is to securitize individuals, not a system of states" (Hoogensen and Rottem 2004, 159 [italics in original]). Rather than categorizing issues of "security" as either responsibilities internal or external to the state, human security with the FST paradigm emphasizes links between local contexts and global processes; both proximal and distal factors relating to the security of the individual are considered, including a wide range of social, political, economic and cultural factors that impact their everyday lives. This problematizes assumptions of responsibility for human security, especially within socio-economically impoverished and politically volatile states, as FST catalyzes "a call for accountability to 'other' people and places, beyond the Euro-American boundaries" (Hyndman 2001, 211).

FST contributes a further dimension to this framework by insisting that there exist specific security issues that are faced primarily, if not solely, by women - especially relating to control over sexuality and freedom from violence. All too often, these issues are obscured or subsumed within other concerns because the prevailing normative frameworks are based on local societal structures as well as on international decision-making arenas that reflect heteronormative masculine, "gender-blind" paradigms that maintain and perpetuate gender inequities and injustices - including violence against women. FST is therefore concerned with "revealing gendered hierarchies, eradicating patriarchal structural violence, and working toward the eventual achievement of common security" (Blanchard 2003, 1305).

In addition to dissolving delineations of "nation" that constitute an internal / external binary of security (as well as responsibility for security), FST also recognizes "the interconnections between local violence such as domestic violence and global violence such as war ... ignoring the former prevents us from fully understanding the causes of the latter" (Hoogensen and Rottem 2004, 169; see also Basch 2004; Blanshard 2003; Hyndman 2001). Violence towards women, as well as their oppression and marginalization at the domestic and community levels, must be viewed within a more expansive lens that includes systemic injustices at national and international levels. Thus far, gender-specific 
concerns have remained peripheral to the mainstream international human security discourse (Blanchard 2003), although increasingly attention is being drawn to insecurities that are faced by girls and women, especially concerning their risk and vulnerability to contracting HIV/AIDS.

In order to combat structural violence that results in human insecurity, including the risk of and vulnerability to HIV/AIDS for women, it is necessary to develop structural approaches based on careful consideration and analysis of specific, localized conditions and contexts and their causal relationship to the disease (Gupta et al. 2008). It is also necessary to consider how "some structural factors might be driving HIV risk or vulnerability proximally, while others will be distal, working through intermediate links or causal pathways" (Gupta et al. 2008, 767-68). The structural factors addressed here include local factors such as the gendered impact of poverty and gender violence, as well as national and global factors responsible for the lack of effective response to specific health, including sexual health, needs of girls and women.

\section{The HIV/AIDS Discourse within Uganda}

Uganda is one of the countries in the world that has been most severely impacted by HIV/AIDS (Genuis and Genuis 2005; Kaiser Family Foundation 2005; Okware et al. 2005). However, the Ugandan government, under President Museveni, made the fight against AIDS a top priority and for a time, predominantly through the early 1990s, Uganda had one of the most successful approaches to combating the disease (Allen 2005; Cohen, Schleifer and Tate 2005; Genuis and Genuis 2005; Green and Witte 2006; Kaiser Family Foundation 2005; Kiapi-iwa and Hart 2004; Okware et al. 2005; Schoepf 2003; Wakabi 2006). The national ABC (Abstinence, Be Faithful, Condom use) campaign worked in conjunction with numerous other multisectoral initiatives (faith-based, non-government, community, and peer) that encouraged and welcomed openness around issues related to HIV/AIDS. The multisectoral initiatives cultivated an environment in which individuals were encouraged to seek information and medical consultation and were also provided with easy access to preventative resources (that is, condoms). Individual behaviour change was an important component of this strategy, but systemic, societal changes, especially 
around issues of women's empowerment, were also key (Schoepf 2003; see also Muriisa, this volume).

This overall comprehensive strategy was extremely successful in reducing HIV-infection levels in the late 1980s and early 1990s. This very success, however, led to subsequent battles over claims of what specific aspect of this overall strategy constituted the reason for success, and over the past several years the discourse around HIV/AIDS prevention in Uganda has become intensely politicized. The current controversy is based upon claims of "what worked" in successful reduction HIV/AIDS: individual behaviour change or a multi-pronged effort based on education, resource /such as condom) mobilization, women's empowerment as well as individual behaviour change.

One faction, led by Christian fundamentalist hardliners such as Ugandan First Lady Janet Museveni, and supported by the United States' former Bush administration, claims that the success of HIV/AIDS reduction can be predominantly attributed to individual behaviour change, and that comprehensive sexual health education and condom distribution, accessibility and use had minimal, if any, impact. The relationship between First Lady Museveni and the former Bush administration was significant because the Presidential Emergency Program For AIDS Reduction (PEPFAR), launched in 2004, provides an enormous bulk of the overall funding for HIV/AIDS prevention programs, with conditionalities that stipulate how this money is to be spent.

The opposing viewpoint, which includes prominent Ugandan politicians, doctors and health workers, representatives of HIV/AIDS support organizations such as The AIDS Support Organization (TASO) and international medical researchers, recognizes the collective importance of all approaches - individual behaviour change, sexual health education, condom use and distribution, community mobilization, an environment of openness, acceptance and empowerment - as key and integral to Uganda's success (for more information on TASO's specific efforts, see Muriisa, this volume).

With respect to the issue of human security, what is most relevant about this controversy over reasons for Uganda's period of success in the battle against HIV/AIDS is that those who claim that individual behaviour change (that is, abstinence, faithfulness) 
accounts for Uganda's success in combating HIV/AIDS insist that the bulk of funding for HIV/AIDS prevention for the general population be spent on abstinence-only programs, and not on the promotion and/or distribution of condoms, or comprehensive sexual health education. Although there seems to be general consensus that the PEPFAR program has been helpful in funding resources and programs that have led to the prevention of HIV infection and care for those suffering from HIV/AIDS, the bilateral nature of the program, the selective nature of funding, and the ideologicallydriven PEPFAR agenda smacks of aid contingent upon neo-colonial conditionalities, where powerful (predominantly wealthy, male) agents in the United States determine what is "best" and "appropriate" for millions of people at risk of HIV/AIDS in the Global South (Ghanotakis, Mayhew and Watts 2009). Mapara (2004) exclaims:

Uganda and Zambia's successes must not be used as scapegoats for Bush's plans or recipe for disaster.... Please do not derail us with the funds that come with strings of "abstinence only" attached to the package.... It is sad that America must dictate on what is best for everybody else. It is simply immoral, outrageous and unethical.

Schoepf (2003) recounts a report made by Edward Green, a member of the former US President Bush's AIDS Advisory Council, to the US Congress, in which he "downplayed the role of condoms in Uganda's ABC approach ... objected that condoms are disliked by Ugandans, are little used and not 100 per cent effective ... [and are] a western, technological solution, inappropriately exported to Africa" (555). Green's position is closely aligned with PEPFAR policy, which stipulates that over fifty per cent of the monies received from the PEPFAR program must be spent on Abstinence / Be faithful programs and that condoms are made available only to "high-risk" groups, such as sex workers, discordant couples and substance abusers and not for the general population (Ghanotakis, Mayhew and Watts 2009). "PEPFAR's mandate has been driven from Washington rather than by local needs, and prioritizes treatment over prevention and an ideology of 'abstinence' and 'be faithful' over 'condom use'" (Ghanotakis, Mayhew and Watts 2009); and this has resulted in a disastrous lack of condom availability (Berry and Noble 2006; Buonocore 2006; Cohen 2005; Cohen and Tate 
2005; Das 2005).

The HIV/AIDS discourse in Uganda has become a pitched site of struggle that puts countless numbers of lives at needless risk. It is irresponsible and unethical to withhold and/or discourage the use of available resources (human and material) that can help securitize lives against HIV/AIDS because the power of resource distribution is held by those who claim the moral high ground on matters of sexuality. These moral and ethical issues raise important questions about structural inequality and its relationship to gender inequality and HIV/AIDS.

\section{Research Findings and Discussion}

From a human security viewpoint, insisting that HIV/AIDS prevention is a matter of individual choice and responsibility assumes that every individual has freedom of choice, the personal power, confidence and knowledge to make and uphold the best decisions possible, decision-making autonomy, and access to the information and resources needed to prevent infection. This is clearly not the case for many young women in Uganda. Similarly, Gupta et al. (2008) argue: "one of the most important justifications for an increased use of structural approaches is to avoid past failure in oversimplified, individually oriented behavioural interventions across diverse populations" (771).

Socio-economic, cultural, political factors operating at both local and international levels render the young women in this study vulnerable to sexual violence, abuse and exploitation and unsecured and unprotected in terms of bodily integrity, freedom of choice and decision-making, and personal power and autonomy. They have restricted capabilities to modify their sexual practices through "individual behaviour change" because the challenges they face stem from deeply systemic gender inequalities:

The HIV/AIDS epidemic has been fuelled by gender inequality. Unequal power relations, sexual coercion and violence are widespread phenomena faced by women of all age-groups, and have an array of negative effects of female sexual, physical and mental health. HIV/AIDS infection reveals the disastrous effects of discrimination against women in the area of human health... (Smith 2002, 64)

Individual girls and women should not be expected to bear the 
burden of deeply-rooted and complex societal problems.

\section{Poverty-induced Sexual Transactions}

Young Ugandan women are in need of money for everything from soap to sanitary napkins to school fees, but those living in extreme poverty have little access to the cash economy. Because of the patriarchal nature of the clan, and the perceived employment opportunities for boys, boys' financial needs often take priority over those of girls (FAWE 2001; GCE 2005; ADF 2005). In addition, many young Ugandan women, particularly in rural areas, have few or no opportunities to earn money through employment. Paid labouring work is scarce, and that which is available to youth is almost always offered to, and taken up by, boys (Jones 2008; Nyanzi, Pool and Kinsman 2001). This point was reiterated in an interview with a teacher in Uganda in August 2005:

The girls - they lack some money, they have a lot to do. They must invest in someone to help the girls because the boys have a chance - the boy can leave the school and gain work, earn the money for school dues. But a girl cannot do that because they are living with the parents.

Thus, girls living under conditions of extreme poverty are often driven to have sex for money. In this study, twelve of the thirteen girls who responded to Q1 indicated that transactional sex to pay for school fees was a common practice for girls. Four of the girls said they themselves had engaged in transactional sex to raise money for their own school fees and related expenses. In Q1, twelve of the thirteen girls indicated that they knew of parents who had encouraged their daughters to engage in transactional sex to finance schooling. As one girl noted (focus group January 2005):

Our mother can force us to, to go and practice fornication. If you say at home, "Mum, I want books, pencils. I don't have a uniform," she can tell you that "I don't have money. What can you do? You can go and practice fornication in order to get money."

By the time the girls responded to Q2 (a year and a half later) ten of the girls were sexually active and nine girls noted that they had received gifts or money for sex. Some of their comments included:

I used that money to buy things that helped me to stay at school because I was at home lacking things to use. It is true that girls 
usually expect money or gifts in exchange for sex because some parents failed to pay school fees for girls and then she decide to exchange sex in order to get money.

Transactional sex generally occurs with men who are older than the girls because older men typically have more money than boys the girls' own age (Vavrus 2005). This is highly problematic, as it is posited that intergenerational sex is one of the key reasons young women are up to six times more likely to become infected with HIV/AIDS than young men their age (Hallett et al. 2007; Kelly et al. 2003). Although transactional sex is widely acknowledged to be a common practice, little has been done to approach this problem in a systematic way. Meeting the needs of young women who engage, or are at risk of engaging, in transactional sex must be taken on as a responsibility of the larger society to fulfill young women's human security needs.

\section{Sexual Abuse and Exploitation}

Girls in Uganda ... fear to talk ... they just keep quiet which is not good at all. They also face the problem of being forced [to have sex] by some people such as teachers, doctors, old mans because they fear them. Girls in Uganda have faced the problem of ... los[ing] their chance of education due to unprotected sex (Secondary schoolgirl, Uganda, May 2006).

Sexuality, fear and violence are tragically intertwined for many young women in Uganda and other Sub-Saharan African countries (Hulton, Cullen Wamala Khalokho 2000; Jones and Norton 2007; Leach et al. 2003; Luke 2003; Nyanzi, Pool and Kinsman 2001). In this study, eleven of the twelve girls who responded to Q2 indicated that they had been afraid to refuse sex. One of the most egregious aspects of this problem is that male teachers are very often perpetrators of sexual abuse, violence, and exploitation of their female students. Q1 showed that all thirteen girls knew of girls who had had sexual relations with teachers, and responses to questionnaires given to teachers at both the KSS and the local primary schools revealed that seventeen out of thirty teachers knew of teachers who had had sexual relationships with their students, and twenty out of thirty teachers believe this to be a general problem in Uganda.

Reasons provided by the young women in this study for girls having sex with their teachers included "money and ... marks" and 
"fear." In Q2, three girls said that they had been afraid to refuse sexual advances made by teachers: one girl (who had had sex with her teacher) said, "I was fearing him ... he would have beaten [me] in class and punished me every time." One girl, Florence, who had originally been part of the research group, but had left the school a few months later, wrote to me after I had returned to Canada, explaining that she had left KSS because "At KSS there were male teachers who harassed me after I refused to have sex with them so I had to change the school" (excerpt from letter from Florence, December 2006). Another girl in this study, Caroline, was forced to leave a senior secondary school in 2006 because one of the male teachers was stalking and threatening her because she would not have sex with him.

There also exists fear of sexual assault outside the school. During a girls' Straight Talk Club meeting in January 2005, the girls raised this issue:

Shelley: What [is an issue you would like] to talk about?

Patricia: Sex before marriage.

Shelley: Sex before marriage ... is that a problem for girls, or girls and boys?

Patricia: Girls.

Shelley: Are you talking about girls who are forced to have sex?

Patricia: Yes.

Shelley: Who forces them to have sex? Why are they forced to have sex?

Patricia: The men ...

Shelley: Which men — like the boyfriends, or teachers, or men in the community, or ... ?

Patricia: All men.

Shelley: Is it a serious problem? 
Patricia: Yes.

Shelley: Do you know girls - do you have friends, or do you know other schoolgirls who were forced to have sex?

Patricia: Yes.

Penina: We young girls, we are forced to have sex with other mens - like the teachers, like the ... other mens in the villages....

Shelley: ... So this goes on? This is common?

All girls: Yes.

Penina: And also many rape us.

The extent of sexual violence appears to be a problem of crisis proportions and yet there is relatively little being done to combat the problem and ensure the personal security of young women. The head teacher of KSS, Mr. Masinde, reflected on this issue:

[In] our culture in Africa and Uganda [women] are not very well empowered, that one can state exactly her right, and therefore they have that ... fears, that for example that if a teacher says or suggests that we should do or have sex and I say no, will I be punished? I lose marks or I even have to leave the school eventually. So because of that fear one doesn't exactly know her right, then she gives in ... these girls [need] talks or workshops that they come to know their rights. One of the problems that we have here in Uganda - there are rules, but people don't know these rules, and therefore, they walk in darkness. So, when they have a right but one might not know that this is my right - to do this or not to do it. So one who will pretend to be more enlightened may come on certain and then the other one gives in. In many cases, we do not know our rights (Interview, August 2005]).

Measures to ensure that all girls and women are aware of their rights and are encouraged to exercise them are essential. Such measures should furthermore be treated seriously by institutions 
and the judiciary system. The Government of Uganda has made some efforts to address the issue of the sexual violation of girls in various ways, including the Ugandan Penal Code Act's "defilement law," that states that: "Any person who unlawfully has sexual relations with a girl under the age of eighteen years is guilty of an offence and liable to suffer death" (Byamukama 2009, 8). However, a spokesperson for the African Network for Prevention and Protection against Child Abuse and Neglect (ANPPCAN), Topher Mugumya, explained that there are numerous problems with enforcing the "defilement" law:

Most cases stop at the police stations because the victims fear reproach from the aggressor's family and children feel shy reporting sexual abuse cases. The Police also stifle some cases by denying receipt of any reports from the victims usually after the aggressors bribe the Police, which is unfortunate. However, victims who take the cases to court usually back off saying they had consented so it was not abuse; or the defendants quote other laws such as Sharia law, which says the age of consent is 12 or 13 years (Nanteza 2006).

An interview (October 2004) with a probation officer in Mbale, Western Uganda, revealed the same obstacles to reporting sexual abuse and assault and securing convictions for the perpetrators. The officer told me that very few cases of rape, perhaps two a month, were reported. He said that girls and women are "shy" about reporting sexual assault, and will only do so if there are witnesses. He also made the disturbing comment that the culture "encourages rape." The "girl child instead of saying no, she means yes ... the first sexual relationship is a kind of rape ... struggle is part of the culture" (Interview with Probation Officer, Mbale, October, 2004). This officer's overview and assessment of the problem of sexual assault is indicative of a problematic assumption around law enforcement and the justice system. It is also indicative of vague social, cultural, and legal definitions of what is permissible within the scope of sexual "relationships."

\section{Lack of Comprehensive Sexual Health Education}

Given the risks that girls and young women face with respect to HIV/AIDS, everything possible should be done to provide them with the knowledge and resources they require to protect them- 
selves as much as circumstances permit. Comprehensive sexual health education should be a right for all youth, and should be an obligation for the state and global community to provide. Indeed, there were indications that the Ugandan government was initially committed to fulfilling its obligations in this regard. In 2001, the President's Initiative on HIV/AIDS Strategy on Communication to Youth (PIASCY) was developed; it provided a wide range of in-depth information on topics such as preventing infection (including through the use of condoms), sexual negotiations (such as how to "say no"), and sexual hygiene.

However, when the PIASCY texts were launched, they were immediately withdrawn in response to protests from the evangelical community that they were immoral and promoted promiscuity. This happened to coincide with the introduction of the Bush Administration's PEPFAR initiative that stipulated that programming emphasis be placed on abstinence. The PIASCY texts were then revised to depict sexual relations as appropriate only within marriage and emphasize abstinence as prevention against contracting HIV/AIDS. Information on condom use was lacking, and the message that sex out of wedlock is "bad" and "dangerous" prevailed. This message has clearly had an impact on youth, as one of the male students at KSS made the following comment during a meeting of the sexual health club: "playing sex means reducing your life expectancy" (October 2004).

In 2004, the United States Agency for International Development (for which Green is a consultant) hired the Uganda Program for Human and Holistic Development (UPHOLD) to provide training for forty thousand teachers on the use of these PIASCY materials. Teachers were explicitly instructed not to talk about condoms with their students. Cohen (2005) makes note of some of these teachers' concerns about the training and the new approach to PIASCY:

At the PIASCY training, we were told not to show [pupils] how to use condoms and not to talk about them at our school. In the past, we used to show them to our upper primary classes. Now we can't do that.

President Museveni said there is no use teaching young people about condom use ... because then children will go and experi- 
ment with them. Some teachers said they taught their pupils about condoms anyway because, as one put it, "people don't buy this idea of abstinence, because in Uganda, many girls are using sex to buy their daily bread."

Students at KSS, as at all secondary school students throughout Uganda, received basic sex education through core curricular subjects such as biology, religious education, and health education. It is also taught as part of the (revised) PIASCY in primary schools. However, because of the public resistance to comprehensive sexual health education, many teachers give little more than passing reference to matters pertaining to sexuality and sexual health:

Shelley: Do you talk about any of these important topics in biology? Like, for example, AIDS?

Boys: ...one or two lessons. [Excerpt from Straight Talk Club meeting with boys, October 2004]

One or two lessons about HIV/AIDS in schools is clearly not sufficient sexual health education, especially in a context where all the students knew people who had died of AIDS or were living with HIV/AIDS, and were living with a great deal of anxiety about contracting the disease themselves.

Instead of receiving comprehensive sexual health education through school, students, as several studies reveal, receive much of their information about sex and sex-related matters from informal sources such as friends, peers, clinics, local organizations, newspapers, radio, and Straight Talk (the monthly sexual health newsletter for adolescents distributed to all secondary schools in Uganda) (Hulton, Cullen and Wamala Khalokho 2000; Kinsman et al. 2001; Neema and Bataringaya 2000; Ndyanabangi and Kipp 2000). Like many schools in Uganda, KSS had Straight Talk Clubs for girls and boys, and this was their main source of sexual health information. During my fieldwork, I co-facilitated these clubs with research assistant and librarian Daniel Ahimbisibwe. The high level of engagement of students with the Straight Talk Clubs was highly indicative of their longing for more education on sexual matters.

During an interview with Florence, one of the girls who participated in my research, she expressed her desire for such knowledge: "us, as girls, we want you to talk ... to us about that HIV ... in private ... in certain day we can meet you — there [points] at your home ... 
[because] we don't have a matron." During a girls' Straight Talk Club meeting another girl expressed her desire for more information:

Mary: The government should give materials to those students whose parents don't want to counsel their children.

Shelley: What kind of counselling do you mean?

Mary: - about sex and relationships.

All of the teachers at KSS also expressed the need for sexual health education for students. One teacher, Harold, said:

... today, the girls they have, as you know this in Uganda and it's country wide, that you have this what called the HIV. This is a big problem for the girls. For them, they don't understand really how they can prevent or how they can stop - how they can leave it, so they can acquire, they can continue their education. But they lack - they have the problem of someone who can come on the counselling them and they advise them [Interview, August 2005].

Another teacher, Robert, made the point that girls in rural areas were particularly in need of sexual heath education: "when you compare the two - girls in town and girls in the village - you find that most of the difficult [y] is from the village where they lack some education, sex education" (Interview, August 2005).

Thus, the sexual health education Ugandan girls have received has been inconsistent, patchy, and inadequate (Jones 2008; Mutonyi, Nielsen and Nashon 2007; Kinsman et al. 2001). Ugandan girls are not fully aware of nature of HIV/AIDS and its transmission and they have many unanswered questions about the disease (Mutonyi, Nielsen and Nashon 2007). Young women's right to comprehensive sexual health education is not being met and consequently their ability to protect themselves against infection is dangerously compromised.

\section{Lack of Access to Sexual Health Resources}

James Shelton (2006), of the Bureau for Global Health, US Agency for International Development, based in Washington DC, claims "condoms are a vital backstop for high-risk situations" (1948). And, although sexual health education is inadequate, most youth are 
aware that condoms provide protection against contracting HIV/AIDS (Amuyunzu-Nyamongo et al. 1999; Kinsman et al. 2001; Ndyanabangi and Kipp 2000). In fact, every young woman in this study was aware of the efficacy of condoms. What is problematic is that very few youth use condoms (Hulton, Cullen and Wamala Khalokho 2000; Jones and Norton 2007) and this seems to be inextricably connected to national and global policies that have come to dictate the terms of sexual engagement.

During the pre-PEPFAR years, the Ugandan government freely distributed a national brand of condoms (Enagbu) to health clinics and other public institutions and organizations. In 2004, however, coinciding with the onset of PEPFAR, all Enagbu condoms were recalled, apparently due to issues of quality. The validity of this recall is contentious as it has been claimed that there were no problems with these condoms, other than an unpleasant odour. This recall, and subsequent extremely limited redistribution of condoms to "high-risk" populations (such as sex workers) sparked outrage amongst those who realized the vital roles condoms have to play in the security of lives of many different populations at risk. Ambassador Stephen Lewis, the UN Secretary General's Special Envoy for HIV/AIDS in Africa from 2001 to 2006, said: "there is no question that the condom crisis in Uganda is being driven and exacerbated by Pepfar and by the extreme policies that the administration in the United States is now pursuing'" (as quoted in Altman 2005).

Berry and Noble (2006) report the frustration of leading Ugandans in the area of HIV/AIDS about the resistance by the Ugandan government and PEPFAR policies to the promotion of condom use. They quote Dr. Musinguzi, Director of the Population Secretariat at the Ministry of Finance:

There are some prominent people in government, and some outside, who with the help of conservative agents in the US are stigmatising AIDS, saying that only sinners use a condom. That is the message we are struggling with.

Similarly, Dr. Katamba, Health Co-ordinator of the Ugandan Protestant Medical Bureau states:

Because of the US, our government now says Abstain and Be Faithful only. So people stop trusting our advice. They think we were lying about how condoms can stop AIDS. Confusion is 
deadly (as cited in Berry and Noble 2006).

The retraction of Enagbu condoms, and the failure to fill the demand with other condoms, has made access to condoms extremely difficult, especially for youth. Cost and availability are two fundamental reasons condoms are not used during sexual encounters. One of the girls in this study reported:

The majority [of men and boys] do not use condoms ... they say why do we use condoms for what ... They say "Do AIDS cost money?"

Most students cannot afford to buy and/or do not know how to access condoms. One male student voiced this concern: "Some say they [condoms] are there, yet they are not there at the centre, but what can we do to get them?" (Straight Talk Club meeting; October 2004).

Thus, youth do not have open and supported access to the very resource - condoms - that could save their lives because of policies made not only at the national, but also the international level. This is an example of how risks related to HIV are connected to "distal [causes], working through intermediate links or causal pathways" (Gupta et al. 2008, 767-68). These "extreme policies," as Stephen Lewis referred to the policies related to PEPFAR and anti-condom campaigns, have indisputably put young women's lives at risk and undermined their human security.

\section{Conclusion}

In order to mitigate the threat of HIV/AIDS for young women, systemic factors that contribute to their vulnerability to infection must be researched, considered and addressed. Individual behaviour change is not possible within an environment in which decision-making powers, control over one's own body and sexuality, and educational and material resources are critically limited or wholly absent. Within such contexts, a young woman's freedom to protect herself to the best of her ability is drastically compromised. As Gupta et al. argue:

Sustained progress in HIV prevention requires structural approaches rather than continuing to address individual-level factors. Structural factors can be influenced but until they are, individuals in many settings will find it difficult to reduce their risk and vulnerability $(2008,773)$. 
Findings from this study show that systemic factors for young women in Uganda include: poverty-induced sexual transactions; sexual abuse and exploitation; lack of comprehensive sexual health education; and lack of access to sexual health resources.

Young women's HIV/AIDS-related human security risks are exacerbated by systemic issues at community, national and international levels. At the community level, their basic needs (such as school fees and clothing) are not met and they do not have equal access to employment in order to have an opportunity to meet those needs. Consequently, they engage in transactional sex with older men in the community to access the financial resources they require. Also at the community level is the rampant problem of sexual abuse. This extreme violation of young women's rights requires efforts made at the national and international arenas, as well as within the local community contexts, to ensure not only that effective laws and policies are put in place, but also that they are enforced. In addition, sweeping education and information campaigns are needed to promote the awareness of women's rights because, as the head teacher of KSS commented, "these girls [need] talks or workshops that they come to know their rights." Furthermore, girls and women need to know how and where they can receive support for - and attention to - their grievances.

At the national and international levels, funding and focus must be expended on comprehensive sexual health education and free and easily accessible sexual health resources (such as health care expertise and condoms). For the past few years, PEPFAR priorities focused on individual behaviour change (that is, abstinence), have been drawn up by men in boardrooms in Washington, and have largely determined Uganda's national HIV/AIDS strategy: These priorities have failed to take into consideration the day-today experiences with which young women such as those in this study must contend, thereby denying them the comprehensive sexual health education and access to the sexual health resources that could save their lives.

However, there is now optimism that the "dictatorial" and "ideologically-driven" Bush PEPFAR policies will give way to a more enlightened approach under President Obama based on research that reflects the realities of the particular vulnerabilities to HIV/AIDS. President Obama has indicated that he intends to 
make significant changes to the PEPFAR program such as funding multilateral projects, such as the Global Fund to Fight AIDS, Tuberculosis and Malaria (which will represent the interests of numerous agencies and stakeholders, not just those based in Washington), supporting and promoting comprehensive sexual health education, increasing overall PEPFAR funding, and eliminating conditionalities that restrict HIV/AIDS-related agencies and programs receiving PEPFAR funding from promoting condom-use, so that "best practice, not ideology' would drive US funding for HIV/AIDS programmes" (Plus News 2009; see also Bristol 2008; Kaiser Network 2008ab). In accordance with these pledges, Dr. Eric Goosby, who assumed the position of US Global AIDS Coordinator in June 2009 has made education and prevention his top priorities, and condom use features predominantly in both these areas (Doyle 2009). Thus, the near future may well bring much-needed substantive changes to global policies concerned with HIV/AIDS that acknowledge and confront the human security dimension of the disease, particularly with respect to the ways in which it endangers the lives of young women.

HIV/AIDS-related human security extends far beyond the individual, to the community, the state, and global policy-makers and initiatives. Changes, therefore, must be holistic and societal in nature; they need to examine and address socio-economic, cultural, political, and legalistic sources of sexual violations as well as provide extensive and effective support networks for girls at all levels of society. In order to fulfill human security obligations with respect to young women in the face of HIV/AIDS, it is essential that the conditions and circumstances of their day to day lives in particular contexts, are fully understood and respected so that (1) they can be provided with all the services and resources necessary to take every measure possible to protect themselves against HIV/AIDS; and (2) serious initiatives are undertaken at local, national and global levels to eradicate all gender-based violence and inequities.

\section{Notes}

${ }^{1}$ This study forms part of a larger research project begun in 2003 by Bonny Norton and Maureen Kendrick of the University of British Columbia, which involves longitudinal, qualitative multiple-case studies of literacy 
programs and practices in multiple sites in Uganda. This umbrella project investigates the complex relationship between education, gender and development, with an underlying focus on HIV/AIDS. Findings from the larger research project are being disseminated in diverse contexts (Kendrick and Jones 2008; Kendrick et al. 2006; Jones and Norton 2007).

\section{Bibliography}

African Development Fund (ADF). 2005. Uganda: Multi-sector Country

Gender Profile. Agriculture and Rural Development North East and south Region (ONAR). Tunis-Belvedere, Tunisia: ADF.

Allen, Tim. 2005. "AIDS and Evidence: Interrogating some Ugandan Myths." Journal of Biosocial Science 38: 7-28.

Altman, Lawrence K. 2005. "US Blamed for Condom Shortage in Fighting AIDS in Uganda." New York Times 30 August 2005.

Amuyunzu-Nyamongo, M., L. Tendo-Wambua, B. Babashangire, N.

Nyagero, Y.K. Matasha, and T. Omurwa. 1999. "Barriers to Behaviour Change as a Response to STD Including HIV/AIDS: the East African Experience." African Medical Research, 1-11.

Basch, Linda. 2004. "Human Security, Globalization, and Feminist Visions." Peace Review 16, no.1: 5-12.

Berry, Steve and Rob Noble. 2006. Why Is Uganda Interesting? Avert.org $<$ www.avert.org/aidsuganda.htm>.

Blanchard, Eric M. 2003. "Gender, International Relations, and the Development of Feminist Security Theory." Sign: Journal of Women in Culture and Society 28, no.4: 1289-1312.

Bristol, Nellie. 2008. "Obama vs McCain on Global Health." The Lancet 372, no.9638: 1216-17.

Buonocore, Danielle. 2006. "HIV/AIDS education in Uganda." Future Leaders Summit on HIV/AIDS, Windhoek, Namibia.

Byamukama, Dora C. Kanabahita. 2009. "Effectiveness of Legislation Enacted to Address Harmful Practices against Women in Uganda, Including Maltreatment of Widows and Female Genital Mutilation." United Nations Division for the Advancement of Women's Expert Group Meeting on Good Practices in Legislation to Address Harmful Practices Against Women, Addis Ababa, Ethiopia, 25-28 May.

Cohen, Jonathan. 2005. A Tale of Two Presidential Initiatives: Changes in an HIV Prevention Program in Uganda. GlobalAIDSLink <hrw.org/english/docs/2006/02/01/uganda12591.htm>.

Cohen, Jonathan, Rebecca Schleifer, and Tony Tate. 2005. "AIDS in Uganda: The Human Rights Dimension." The Lancet 365, no.9477: 2075-76. 
Cohen, J. and Tony Tate. 2005. "The Less They Know the Better.

Abstinence-only HIV/AIDS Programs in Uganda." Human Rights

Watch 17, no.4: 1-79.

Das, Pam. 2005. "Condom Crisis in Uganda." The Lancet 5: 601-02.

Doyle, Jim. 2009. "New Global AIDS Chief Goes To Work Immediately."

San Francisco Chronicle 25 June <http://sfgate.com/cgi-bin/ article.cgi?f=/c/a/2009/06/25/MNL118DDJD.DTL $>$.

Dworkin, Shari L. and Anke. A. Ehrhardt. 2007. "Going beyond 'ABC' To Include 'GEM': Critical Reflections on Progress in the HIV/AIDS Epidemic." American Journal of Public Health 97, no.1: 13-18.

Forum for African Women Educationalists (FAWE). 2001. Girls'

Education and Poverty Eradication: FAWE's Response. Third United Nations Conference on the Least Developed Countries, Belgium. Nairobi, Kenya: FAWE.

Garbus, Lisa and Elliot. M. Marseille. 2003. "HIV/AIDS in Uganda." Country AIDS Policy Analysis Project. San Francisco: Aids Policy Research Center, University of California.

Genuis, S.J. and S.K. Genuis. 2005. "HIV/AIDS Prevention in Uganda: Why Has It worked?" Postgraduate Medical Journal 81: 615-17.

Ghanotakis, Elena, Susannah Mayhew, and Charlotte Watts. 2009. "Tackling HIV and Gender-based Violence in South Africa: How Has PEPFAR Responded and What Are the Implications for Implementing Organizations?" Health Policy and Planning 0: czp024va-czp024. Published online on 8 June <http://heapol.oxfordjournals.org/ cgi/content/full/czp024v1>.

Global Campaign for Education (GCE). 2005. Why Girls' Education Matters, and How To Make It Happen Now. Johannesburg: GCE. Green, Edward C. and Kim Witte. 2006. "Can Fear Arousal in Public Health Campaigns Contribute to the Decline of HIV Prevalence?" Journal of Health Communication 11, no.3: 245-59.

Gupta, Geeta Rao, Judith O. Parkhurst, Jessica A. Ogden, Peter Aggleton, and Ajay Mahal. 2008. "Structural Approaches to HIV Prevention." The Lancet 372: 764-75.

Hallett, T.B., S. Gregson, J.J. C. Lewis, B.A. Lopman, and G.P. Garnett. 2007. "Behaviour Change in Generalized HIV Epidemics: Impact of Reducing Cross-generational Sex and Delaying Age at Sexual Debut." Sexually Transmitted Infections 83: 50-54.

Hoogensen, Gunhild, and Svein Vigeland Rottem. 2004. "Gender Identity and the Subject of Security." Security Dialogue 35, no.2: 155-71.

Hulton, Louise.A., Rachel Cullen, and Symons Wamala Khalokho. 2000. "Perceptions of the Risks of Sexual Activity and Their Consequences among Ugandan Adolescents." Studies in Family Planning 31, no. 1: 35-46. 
Hyndman, Jennifer. 2001. "Towards a Feminist Geopolitics: The Inaugural Suzanne Mackenzie Memorial Lecture." Canadian Geographer 45, no.2: 210-22.

Plus News. 2009. "A New and Improved PEPFAR under Obama?" Plus News, Global HIV/AIDS News and Analysis. IRIN $<$ http://www.plusnews.org/report.aspx?ReportId=82494>.

Jones, Shelley Kathleen. 2008. "Secondary Schooling for Girls in Rural Uganda: Challenges, Opportunities and Emerging Identities." PhD thesis. University of British Columbia, Canada.

Jones, Shelley, and Bonny Norton. 2007. "On the Limits of Sexual Health Literacy: Insights from Ugandan Schoolgirls." Journal of Diaspora, Indigenous and Minority Education 1, no.4: 285-305. . 2010. "Uganda's ABC Program on HIV/AIDS Prevention: A Discursive Site of Struggles." In Applied Linguistics in the Field: Local Knowledge and HIV/AIDS, edited by C. Higgins and B. Norton. Bristol, UK: Multilingual Matters.

Kaiser Family Foundation. 2005. "The HIV/AIDS Epidemic in Uganda: Fact Sheet" <www.kff.org/hivaids/upload/7368.pdf >.

Kaiser Network. 2008a. "Barack Obama: Fighting HIV/AIDS Worldwide." <http://www.kaisernetwork.org/election2008/OBAMAFactSheetAI DSFINAL.pdf $>$. . 2008b. "Obama Likely To Reverse Some Bush Administration HIV/AIDS Prevention, Family Planning Policies, Adviser Says" $<$ http://www.kaisernetwork.org/Daily_reports/rep_index.cfm?DR_I $\mathrm{D}=55471>$.

Kelly, Robert J., Ronald H. Gray, Nelson K. Sewankambo, David Serwadda, Fred Wabwire-Mangen, Tom Lutalo, and Maria J. Wawer. 2003. "Age Differences in Sexual Partners and Risk of HIV-1 Infection in Rural Uganda." Journal of Acquired Immune Deficiency Syndromes 32, no.4: 446-51.

Kendrick, Maureen, and Shelley Jones. 2008. "Girls' Visual Representations of Literacy in a Rural Ugandan Community." Canadian Journal of Education 31, no.2: 371-404.

Kendrick, Maureen, Shelley Jones, Harriet Mutonyi, and Bonny Norton. 2006. "Multimodality and English Education in Ugandan Schools." English Studies in Africa 49, no.1: 95-114.

Kiapi-iwa, L. and G.J. Hart. 2004. "The Sexual and Reproductive Health of Young People in Adjumani District, Uganda: Qualitative Study of the Role of Formal, Informal and Traditional Health Providers." AIDS Care 16, no.3: 339-47. 
Kinsman, J., J. Nakiyingi, A. Kamali, L. Carpenter, M. Quigley, R. Pool, and J. Whitworth. 2001. "Evaluation of a Comprehensive schoolbased AIDS education program in rural Masaka, Uganda." Health and Education Research 16, no.1: 85-100.

Kuate-Defo, Barthelemy. 2004. "Young People's Relationships with Sugar Daddies and Sugar Mummies: What Do We Know and What Do We Need to Know?" African Journal of Reproductive Health 8, no.2: 1337.

Leach, Fiona, Vivian Fiscian, Esme Kadzamira, Eve Lemani, and Pamela Machakanja. 2003. An Investigative Study of the Abuse of African Girls in School. London: DFID.

Lewis, S. 2005. Race against Time. Scarborough, Ontario, Canada: HarperCollins.

Luke, Nancy. 2003. "Age and Economic Asymmetries in the Sexual Relationships of Adolescent Girls in Sub-Saharan Africa." Studies in Family Planning 34, no.2: 67-86.

Malinga, Florence. 2001. "Uganda: Designing Communication and Education Programs to Combat HIV/AIDS. Association for the Development of Education in Africa Newsletter 12, no.4 $<$ http://www.adeanet.org/newsletter/Vol12No4/08.html>. TunisBelvedere, Tunisia: ADEANET.

Mirembe, Robina and Lynn Davies. 2001. "Is Schooling a Risk? Gender, Power, Relations, and School Culture in Uganda." Gender and Education 13, no.4: 401-16.

Mapara, Edwin M. 2004. "One Spider's Web Cannot Tie Up a Lion!” BMJ $<$ http://www.bmj.com/cgi/eletters/329/7459/192-a>.

Mutonyi, Harriet, Wendy Nielsen, and Samson Nashon. 2007. "Building Scientific Literacy: A Case Study of Uganda." International Journal of Science Education 29, no.11: 1363-85.

Nanteza, Patricia. 2006. "Uganda - Child Sexual Abuse on the Rise." The Monitor 13 November 13.

Ndyanabangi, Bannet and Walter Kipp. 2000. "Reproductive Health and Adolescent School Students in Kabarole District, Western Uganda: A Qualitative Study." World Health and Population 3, no. 2.

Neema, Stella and Denis Bataringaya. 2000. Research on Adolescent Sexual and Reproductive Health in Uganda: A Documents Review. Document review presented to Africa Alive. New York: Alan Guttmacher Institute.

Nyanzi, S., R. Pool, and J. Kinsman, J. 2001. "The Negotiation of Sexual Relationships among School Pupils in South-western Uganda." AIDS Care 13, no.1: 83-98. 
Okuonzi, Sam A. and Helen Epstein. 2005. "Pragmatic Safe Sex, Not Abstinence or Faithfulness, Was Key in Uganda's HIV Decline." Health Policy and Development Journal 3, no.1: ii-iii.

Okware, S., J. Kinsman, S. Onyango, A. Opio, and P. Kaggwa. 2005.

"Revisiting the ABC strategy: HIV Prevention in Uganda in the Era of Antiretroviral Therapy." Postgraduate Medical Journal 81: 625-28 <http://pmj.bmj.com/cgi/content/abstract/81/960/625>. Accessed 14 January 2008.

Roberts, Kabeba Muriisa. 2006. The AIDS Pandemic in Uganda: Social Capital and the Role of NGSs in Alleviating the Impact. PhD thesis, University of Bergen.

Schoepf, B.G. 2003. "Uganda: Lessons for AIDS Control in Africa." Review of African Political Economy 30, no.98: 553-72.

Shelton, James D. 2006. "Confessions of a Condom Lover." The Lancet 368: 1947-49.

Smith, Mohga Kamal. 2002. "Gender, Poverty, and Intergenerational Vulnerability to HIV/AIDS." Gender and Development 10, no.3: 6370.

Uganda Bureau of Statistics. 2002. Kampala, Masaka, Mpigi, Mubende and Mukono Districts: Socio-economic Conditions Based on the 1999/2000 Uganda National Household Survey. Entebbe, Uganda.

Vavrus, Frances. 2005. "Adjusting Inequality: Education and Structural Adjustment in Tanzania." Harvard Educational Review 75, no.2: 174-201.

Wakabi, Wairagala. 2006. "Condoms Still Contentious in Uganda's Struggle over AIDS." The Lancet 367, no.9520: 1387-88. 